\title{
PENEGAKAN HUKUM DALAM PENANGGULANGAN PROSTITUSI DI KABUPATEN DEMAK
}

\author{
Anastasia Hani Prasetio, Safik Faozi \\ Fakultas Hukum, Universitas Stikubank (UNISBANK) Semarang \\ E-mail : anastasiahanie55@gmail.com, safikfaozi@edu.unisbank.ac.id
}

\begin{abstract}
ABSTRAK
Prostitusi merupakan tindakan yang menyimpang dan menyalahi aturan nilai- nilai dan norma- norma sosial maupun agama. Prostitusi yang melibatkan para pihak seperti mucikari, pekerja seks komersial, dan pengguna jasanya datang dari berbagai kalangan yang disebabkan karena faktor ekonomi dan kurang kuatnya mental dalam mengahadapi perubahan global masyarakat yang berubah ke era modern, serta tuntutan gaya hidup dimana nilai dan norma yang ada di dalam masyarakat mulai tergerus oleh perubahan zaman yang semakin berkembang.

Metode pendekatan yang digunakan dalam penelitian ini adalah yuridis normatif, spesifikasi penelitian secara in concreto, sumber data sekunder, data yang diperoleh akan dianalisis secara kualitatif. Hasil penelitian menunjukkan bahwa Penegakan hukum dalam penanggulangan prostitusi di Kabupaten Demak dilaksanakan dengan model penegakan Actual enforcement law .muncul setelah diyakini adanya diskresi dalam penegakan hukum karena keterbatasanketerbatasan, baik yang berkaitan dengan sarana- prasarana, kualitas sumber daya manusianya, kualitas perundang- undangannya dan kurangnya partisipasi masyarakat. Aparat penegak hukum meliputi Satuan Polisi Pamong Praja, Kepolisian KabupatenDemak, dan Dinas Sosial. Hambatan yang terjadi dalam penegakan hukum dalam penanggulangan prostitusi di Kabupaten Demak antara lain karena faktor hukumnya meliputi ; didalam bunyi nomra- norma Peraturan Daerahnya kurang jelas sehingga dapat ditawar dengan kata lain tidak sesuai dengan aturan tersebut, faktor penegak hukumnya; aparat penegak hukum yang kurang tegas, aparat penegak hukumnya lebih mengutamakan asas kemanusiaan, dan kurangnya personil, faktor sarana dan fasilitas meliputi ; belum adanya rumah rehabilitasi untuk menampung para pelaku penyakit masyarakat (PSK) dan tidak adanya pendanaan untuk menindak tegas para pelaku sampai ke proses peradilan, faktor masyarakat meliputi; masyarakat kurang berpartisipasi dalam melaporkan adanya kegiatan praktek prostitusi disekitar mereka, dan adanya backing/preman atau germo yang melindungi para pekerja seks komersial untuk memberikan informasi lebih awal sehingga bisa melarikan diri, faktor kebudayaan meliputi; Kebudayaan masyarakat yang sudah melekat sejak dulu sudah mulai ditinggalkan, dan adanya budaya kota yang modern masuk keKabupatenDemak.
\end{abstract}

\section{Kata kunci : Penegakan Hukum, Penanggulangan Prostitusi}




\begin{abstract}
Prostitution is an act that deviates and violates the rules of social and religious values and norms. Prostitution involving parties such as pimps, commercial sex workers, and service users comes from various circles due to economic factors and lack of mental strength in dealing with global changes in society that changed to the modern era, as well as lifestyle demands where values and norms exist in in society began to be eroded by the changing times that are increasingly developing.

The method used in this research is normative juridical, research specifications in concreto, secondary data sources, the data obtained will be analyzed qualitatively. The results showed that law enforcement in the handling of prostitution in Demak Regency was carried out using the model of actual enforcement law. It emerged after the discretion in law enforcement was believed to be due to limitations, both related to infrastructure, quality of human resources, quality of legislation and lack of community participation. Law enforcement officers include the Civil Service Police Unit, Demak District Police, and Social Services. Obstacles that occur in law enforcement in the prevention of prostitution in Demak Regency are due to legal factors including; in the sound of the Regional Regulation numbers are unclear so that it can be bargained in other words not in accordance with these rules, law enforcement factors; law enforcement officials are less assertive, law enforcement officials prioritize the principle of humanity, and the lack of personnel, factors and facilities include; the absence of rehabilitation houses to accommodate community disease perpetrators (CSWs) and lack of funding to crack down on perpetrators to the judicial process, community factors include; the community is less participating in reporting the practice of prostitution around them, and there are backing / thugs or pimps who protect commercial sex workers to provide information early so they can escape, cultural factors include; The inherent community culture has long since begun to be abandoned, and the existence of a modern city culture has entered the Demak District.
\end{abstract}

Keywords: Law Enforcement, Prevention of Prostitution 


\section{Pendahuluan}

Prostitusi merupakan tindakan menyimpang yang menyalahai aturan nilai- nilai dan norma agama, dimana dalam prostitusi melibatkan Pekerja seks komersial yang dipengaruhi karena kurang kuatnya mental dalam perubahan global yang modern. Salah satu faktor yang mempengaruhi yaitu ekonomi dan tuntutan gaya hidup dimana nilai dan norma kehidupan masyarakat mulai tergerus oleh perubahan zaman.

Dari tinjauan yuridis, ada beberapa pasal yang mengatur didalamnya mengenai prostitusi, yaitu Pasal 296, Pasal 297 Kitab Undang- Undang Hukum Pidana (KUH) yang berbunyi "Barang siapa mereka yang sengaja menghubungkan atau memudahkan perbuatan cabul oleh orang lain, dan menjadikannya sebagai pencarian atau kebiasaan, diancam dengan pidana penjara paling lama satu tahun empat bulan dan denda paling banyak seribu rupiah; Perdagangan wanita dan perdagangan anak lakilaki yang belum cukup umur, diancam dengan pidana penjara paling lama enam tahun". Mesikupun sudah ada aturan dan larangan namun masih saja terjadi praktek prostitusi yang secara gamblang dan terang- terangan dilakukan oleh para pelakunya dan masih sering terjadi di Indonesia tidak hanya di wilayah perkotaan saja melainkan juga di Kabupaten. Sanksi pidana dalam hukum positif di Indonesia mengatur tentang hukuman bagi mereka yang menjalankan praktek Pekerja Seks Komersial (PSK), yang diatur secara tegas dan jelas dalam 506 kitab undang - undang hukum pidana (KUHP) yang berbunyi : "barang siapa menarik keuntungan dari perbuatan cabul seorang wanita dan menjadikan sebagai pencarian diancam hukuman paling lama satu tahun"

Kabupaten Demak merupakan salah satu kota yang terdapat praktek prostitusi Pekerja seks komersial (PSK). Salah satu faktor yang menyebabkan seseorang menjadi Pekerja seks komersial dan terjerumus dalam praktek prostitusi yaitu karena masalah ekonomi dan kenaikan harga kebutuhan hidup sehari-hari, karena masalah keluarga ditinggalkan oleh suami sehingga harus mencari nafkah sendiri untuk memenuhi kebutuhan, dan tuntutan gaya hidup.

Upaya penegakan hukum sebagai salah satu pilar demokrasi dipengaruhi oleh empat faktor, yaitu:

1) Faktor hukumnya sendiri;

2) Faktor penegak hukumnya;

3) Faktor sarana-prasarana;

4) Faktor masyarakat;

5) Faktor kebudayaan.

Aparat penegak hukum berwenang dalam upaya penanggulangan dan penegakan hukum atas praktek prostitusi adalah Satuan Pamong Praja, yang seterusnya disingkat Satpol PP dan Polres Kabupaten Demak.Satpol PP bertugas menegakkan Perda dan menyelenggarakan ketertiban umum dan ketentraman masyarakat serta perlindungan masyarakat, sesuai Peraturan Pemerintah Republik Indonesia Nomor 6 Tahun 2010 Tentang Satuan Pamong Praja dan Kepolisian berdasarkan UndangUndang RI No. 2 Tahun 2002 Tentang Undang-Undang Kepolisian Negara mempunyai fungsi Pemerintah Negara di bidang 
pemeliharaan keamanan dan ketertiban masyarakat, penegak hukum, perlindungan, pengayoman, dan pelayanan kepada masyarakat.

Penegakan hukum oleh Satpol

PP dan Kepolisian terhadap prostitusi berdasarkan Perda Nomor 2 Tahun 2015 tentang Penanggulangan Penyakit Masyarakat di Kabupaten Demak.Meskipun demikian praktek Prostitusi oleh Pekerja Seks Komersial (PSK) masih terjadi di Kabupaten Demak.

Secara teori jenis penegakan hukum pidana mencakup penegakan hukum pidana yang bersifat Total enforcement law, Full enforcement law, dan Actuall enforcement law.

Berdasarkan uraian dari latar belakang yang telah dikemukakan diatas, maka perumusan masalah yang timbul dalam penelitian adalah sebagai berikut :

1. Bagaimana penegakan hukum dalam penanggulangan Prostitusi di Kabupaten Demak?

2. Hambatan apa saja yang terjadi dalam penegakan hukum terhadap Prostitusi di Kabupaten Demak ?

\section{Metode Penelitian}

Penelitian tentang "Penegakan Hukum dalam Penanggulangan Prostitusi di Kabupaten Demak" ini merupakan suatu penelitian dengan menggunakan cara pendekatan yuridis normatif .

Fokus penelitian yang digunakan dalam skripsi ini adalah penelitian hukum in concreto. Penelitian hukum in concreto merupakan suatu penelitian untuk menemukan hukum bagi suatu perkara in concreto merupakan suatu usaha apakah hukumnya yang sesuai untuk diterapkan in concreto guna menyelesaikan perkara tertentu.

Data yang dikumpulkan adalah data yang berhubungan dengan peraturan yang berlaku yakni Kitab Undang- Undang Hukum Pidana (KUHP), Peraturan Daerah Kabupaten Demak Nomor 2 Tahun 2015 tentang Penanggulangan Penyakit Masyarakat di Kabupaten Demak, serta pengumpulan data dalam penelitian ini ditunjang dengan wawancara dengan para aparat penegak hukum di Kabupaten Demak seperti Polisi Satuan Pamong Praja dan Kepolisian Shabara.

\section{Pembahasan}

1. Penegakan hukum dalam penanggulangan Prostitusi di Kabupaten Demak

Penegakan hukum dalam menanggulangi praktek prostitusi yang meresahkan masyarakat sekitar di Kabupaten Demak dengan membuat sebuah peraturan atau larangan terjadinya praktek prostitusi yang dikawasan Kabupaten Demak yaitu Peraturan Daerah Nomor 2 Tahun 2015 tentang Penanggulangan Penyakit Masyarakat di Kabupaten Demak. Peraturan atau larangan terhadap praktek prostitusi di Kabupaten Demak dijalankan oleh Satuan Polisi Pamong Praja, Kepolisian Kabupaten Demak, dan Dinas Sosial yang bekerjasama dengan Panti Rehabilitasi "Wanita Utama" di Solo.

Menurut pasal $13 \mathrm{BAB}$ VI : 
Barang siapa yang melakukan kegiatan pelacuran di Kabupaten Demak diancam hukuman sebagaimana diatur dalam Peraturan Daerah ini.

Pasal 14 :

(1) Barang siapa yang mengkoordinasi atau menampung pelacuran dan atau menyediakan sarana dan prasarana yang dapat digunakan sebagai tempat untuk menampung pelacur, baik untuk melakukan maupuan tidak melakukan kegiatan pelacuran diancam hukuman sebagaimana diatur dalam Peraturan Daerah ini.

(2) Terhadap sarana dan prasarana yang digunakan sebagaimana yang dimaksud pada ayat (1) dapat dilakukan penutupan atau penyegelan.

Larangan : Pasal 19

(1) Setiap orang dilarang :

a. Melakukan kegiatan pelacuran;

b. Mengkoordinasi atau menampung pelacur dan/atau menyediakan sarana dan prasarana yang dapat digunakan sebagai tempat untuk menampung pelacur;

(2) Badan dilarang :

a. Mengkoordinasi atau menampung pelacur dan/atau menyediakan sarana dan prasarana yang dapat digunakan sebagai tempat untuk menampung.

Ketentuan Pidana : Pasal 24

1. Setiap orang yang melanggar Pasal 19 ayat (1) huruf $\mathrm{f}$ diancam dengan pidana kurungan paling lama 7 (tujuh) hari dan/atau denda paling banyak Rp 5.000.000,(lima juta rupiah).

2. Setiap orang atau Badan yang melanggar Pasal 19 ayat (1) huruf $g$ dan ayat (2) huruf e diancam dengan pidana kurungan paling lama 3 (tiga) bulan dan/atau denda paling banyak Rp 50.000.000,(lima puluh juta rupiah).

Jenis penegakan hukum menurut Joseph Goldstein membedakan penegakan hukum pidana menjadi 3 bagian yaitu:

1. Total enforcement law, yakni yang menuntut agar semua nilai yang ada dibelakang norma hukum tersebut ditegakkan tanpa terkecuali.

2. Full enforcement law, yang menyadari bahwa konsep total perlu dibatasi dengan hukum acara dan sebagainya demi perlindungan kepentingan individual.

3. Actual enforcement law, yang muncul setelah diyakini adanya diskresi dalam penegakan hukum karena keterbatasanketerbatasan, baik yang berkaitan dengan saranaprasarana, kualitas sumber daya manusianya, kualitas perundangundangannya, dan kurangnya partisipasi masyarakat. 
Penegakan hukum terhadap penanggulangan prositusi di Kabupaten Demak menggunakan Actual enforcement law, karena para aparat penegak hukum lebih memilih upaya preventif dengan tujuan untuk mementaskan dan memasyarakatkan pekerja seks komersial yang terjaring operasi dengan melakuakn pembinaan dan rehabilitasi serta memberikan keterampilan menjahit, salon/kecantikan, dan tata boga, dengan harapan sepulangnya dari rehabilitasi sealama 6 bulan ini, mantan pekerja seks komersial bisa membuka usaha dan akan diberikan modal usaha sesuai dengan minat bakat yang telah diberikan selama dalam rehabilitasi. Tidak hanya itu, mantan pekerja seks komersial yang berprestasi akandisalurkan perusahaan yang telah pekerjasama dengan Pati Rehabilitasi untuk dapat bekerja di perusahaan tersebut.

Aparat penegak hukum Kabupaten Demak termasuk dalam jenis penegakan hukum Actual enforcement law, sebab adanya keterbatasanketerbatasan dalam saranaprasarana, kualitas sumber daya manusianya, kualitas perundang- undangannya dan kurang partisipasi dari masyarakat, akibatnya membuat peraturan daerah tidak bisa berjalan secara maksimal dalam penegakannya.
Upaya pemerintah dalam menanggulangi penyakit sosial terutama terutama wanita pekerja seks komersial melalui Peraturan Daerah Nomor 2 Tahun 2015 tentang penanggulangan penyakit masyarakat di Kabupaten Demak berjalan kurang efektif sesuai dengan apa yang diharapkan oleh peraturan atau undang- undang yang berlaku di Kabupaten Demak. Praktek prostitusi masih saja tetap dilakukan, hal ini bisa dilihat diberbagai titik- titik rawan yang berada di sepanjang jalan lingkar Demak, tempat- tempat karaoke, warung remangremang, persawahan dan sepanjang tanggul sungai yang berada di jalan raya DemakKudus. Bahkan sampai juga di kawasan pinggiran Semarang yaitu Mranggen.

Pemerintah dianggap kurang serius dalam menjalankan Peraturan Daerah, hal ini dapat dilihat dari penegakan hukum terhadap pekerja seks komersial yang kurang maksimal sehingga dapat membuat pelaku pekerja seks komersial tidak jera. Padahal dalam peraturan daerah sudah jelas disebutkan ancaman pidana bagi pekerja seks komersial yaitu 3 bulan kurungan atau denda maksimal Rp 50.000.000 (lima puluh juta rupiah). Tetapi dalam kenyataannya penjatuhan pidana bagi pelanggar yang dilakukan oleh pekerja seks komersial di Kabupaten Demak belum pernah terjadi 
penjatuhan pidana secara maksimal atau hukuman yang berat bagi pekerja seks komersial di Kabupaten Demak.

Aparat penegak hukum Satuan Polisi Pamong Praja memilih untuk membawa para wanita pekerja seks komersial yang terjaring operasi yustisial ke Panti Rehabilitasi Sosial Wanita Utama di Solo untuk diberikan pelatihan dan ketrampilan seperti menjahit, salon/kecantikan, dan tata boga, dengan tujuan mengentaskan agar tidak kembali bekerja menjadi wanita pekerja seks komersial yang beroperasi di Kabupaten Demak. Satpol PP lebih mengedepankanasas

kemanusiaan sebagai dasar melakukan rehabilitasi, dan sering kali para pelaku pekerja seks komersial yang tertangkap tidak mampu membayar denda.

\section{Hambatan Yang Terjadi} Dalam Pelaksanaan

Penegakan Hukum Dalam Penanggulangan Prostitusi Di Kabupaten Demak

Dalam penengakan hukum dalam penanggulangan prostitusi di Kabupaten Demak ini, masih saja ada beberapa hambatan yang dipengaruhi oleh beberapa faktor- faktor diantaranya :

a) Faktor hukumnya, Pemerintah Kabupaten Demak telah membuat aturan didalamnya terdapat aturan dan larangan tentang penanggulangan penyakit masyarakat dalam

Peraturan Daerah Nomor 2

Tahun 2015 tentang penanggulangan penyakit masyarakat di Kabupaten Demak, tetapi bunyi normanoma didalam Peraturan Daerah tersebut kurang jelas sehingga aturan dan larangannya dapat ditawar dengan kata lain menggunakan penegakan yang tidak sesuai dalam aturan Peraturan Daerah Nomor 2 Tahun 2015 tentang penanngualangan penyakit masyarakat.

b) Faktor penegak hukum, Dalam permasalahan penyakit masyarakat di Kabupaten Demak, penegak hukum yang berkecimpung meliputi Satuan Polisi Pamong Praja, Kepolisian SHABARA, dan Dinas Sosial. Kepolisian Resor Kabupaten Demak faktor yang menghambat penegak hukum dalam penanggulangan prostitusi menjelaskan bahwa Pemerintah pusat tidak memberikan biaya untuk melaksanakan penegakan tindak pidana ringan dalam proses persidangan, sehingga menyulitkan aparat penegak hukum untuk melaksanakan peraturan sesuai yang telah di atur di dalam PERDA, serta kurangnya personil penegak hukum dalam menjalankan

penanggulangan penyakit 
$\begin{array}{lr}\text { masyarakat } & \text { terutama } \\ \text { prostitusi. } & \text { Dengan } \\ \text { demikian } & \text { Kepolisian } \\ \text { SHABARA } & \text { untuk } \\ \text { menindaklanjuti } & \text { masalah } \\ \text { tindak pidana } & \text { ringan, } \\ \text { menyerahkan } & \text { kepada }\end{array}$

Satuan Polisi Pamong Praja untuk dilakukannya pembinaan dan rehabilitasi.

c) Faktor sarana dan fasilitas, Berdasarkan hasil wawancara dari Bapak Rozikan selaku kasi Penyuluhan dan Pembinaan Satpol PP Kabupaten Demak Hari Rabu 20 Maret 2019, menjelaskan bahwa, Pemerintah Kabupaten Demak belum menyediakan tempat untuk penampungan atau rehabilitasi untuk para pelaku pekerja seks komersial yang terjaring razia serta pembinaan sesuai minat bakat masingmasing, sehingga Pemerintah Kabupaten Demak dalam melakukan rehabilitasi masih bekerjasama dengan Panti Rehabilitasi Sosial Wanita Utama di Solo yang berada dalam pengawasan Dinas Sosial Jawa Tengah.

d) Faktor masyarakat, Berdasarkan wawancara dari Bapak Rozikan selaku Kasi Penyuluhan dan Pembinaan Peraturan Daerah Satuan Polisi Pamong Praja Kabupaten Demak pada tanggal 20 Maret 2019 menjelaskan bahwa, hanya saja kurangnya kesadaran masyarkat akan pentingnya aturan hukum itu ditegakkan membuat aparat penegak hukum kesulitan untuk melaksanakannya, kurang dukungan atau kurang sadarnya bahaya penyakit masyarakat seperti seks bebas dan penyakit yang menular (HIV) akan berdampak buruk bagi kehidupan dimasa mendatang, serta berdampak buruk bagi generasi penerus, serta adanya Backing/preman, dan/atau germo yang melindungi pekerja seks komersial untuk memberikan informasi terkait akan diadakannya operasi yang akan dilakukan oleh aparat penegak hukum sehingga sebelumnya dapat melarikan diri atau kabur agar tidak tertangkap operasi.

e) Faktor kebudayaan, faktor kebudayaan yang sebenarnya menyatu dengan faktor masyarakat sengaja dibedakan, karena di dalam hal pembahasannya

diketengahkan masalah sistem nilai-nilai yang menjadi inti dari kebudayaan spiritual atau non-materiel. Masyarakat di Kabupaten Demak sangat menjujung tinggi nilai- nilai keagamaan, hal ini dipengaruhi oleh leluhur masyarakat Kabupaten Demak yang menjadi salah 
satu tokoh penyebaran agama islam di pulau jawa yang dikenal dengan wali sembilan.

Peningkatan pekerja seks komersial yang terjaring razia di Kabupaten Demak terjadi semenjak banyaknya pedirian café- café, warung kopi remang- remang, tempat hiburan karaoke di sepanjang jalan raya lingkar DemakKudus di Kabupaten Demak, persawahan dan sepanjang pinggiran sungai di sepanjang jalan Demak- Kudus. Pekerja seks komersial biasanya mengincar para supir kendaraan besar yang melintas di sepanjang jalan raya Kabupaten Demak tetapi tidak terpungkiri pelanggan juga datang dari kalangan warga sekitar.

\section{Simpulan}

Penegakan hukum dalam penanggulangan prostitusi di Kabupaten Demak menggunakan jenis penegakan hukum Actual enforcement law, yaitu karena munculnya adanya diskresi dalam penegakan hukum karena keterbatasan- keterbatasan yang berakitan didalamnya saranaprasarana di Kabupaten Demak yang kurang memadai seperti belum adanya panti rehabilitasi untuk menampung para pekerja seks komersial, kualitas sumber daya manusia di Kabupaten Demak yang kurang memadai seperti didalamnya meliputi aparat penegak hukumnya yang kurang tegas serta lebih mengutamakan rasa kemanusiaan dan masyarakat yang kurang berpartisipasi dalam hal untuk menanggulanginya, perundangundangan yang mengaturnya kurang jelas sehingga aturan didalamnya tidak dapat berjalan sesuai dan maksimal.

Hambatan yang terjadi dalam proses penegakan hukum terhadap prostitusi di Kabupaten Demak diantaranya karena dipenagruhi oleh beberapa faktor, yaitu faktor hukumnya sendiri atau Peraturan Daerah/Undang- undang yang bunyi norma- norma didalam Peraturan Daerah tersebut kurang jelas sehingga aturan dan larangannya dapat ditawar dengan kata lain menggunakan penegakan yang tidak sesuai dalam Peraturan Daerah Nomor 2 Tahun 2015 tentang Penanggulangan Penyakit Masyarakat di Kabupaten Demak. Aparat penegak hukumnya dalam menegakan/ menanggulangi penyakit masyarakat kurang tegas, aparat penegak hukum Kabupaten Demak sangat mengutamakan asas kemanusiaan, kurangnya personil dalam proses penegakan hukum untuk menanggulangi prostitusi. Belum adanya tempat rehabilitasi sendiri di Kaupaten Demak, masyarakat yang kurang sadar untuk berpartisipasi membantu dalam proses penanggulangan. Para pekerja seks komersial sering kali juga ada yang melindungi yang biasa disebut Backing, Era gblobalisasi yang modern mulai menggerus kebudayaan masyarakat mengenai nilai- nilai dan norma- norma agama yang sejak dulu tertanam mulai hilang sedikit demi sedikit dan mulai diterapkan di masyarakat Kabupaten Demak. 


\section{Saran}

Dalam penegakan hukum untuk menanggulangi prostitusi di Kabu paten Demak sebaiknya Pemerintah Kabupaten Demak diharapkan mengupayakan sarana dan fasilitas yang mendukung dalam penegakan hukum terhadap prostitusi, dengan membuatkan rumah rehabilitasi sendiri untuk menampung para pelaku penyakit masyarakat agar mementaskan dari permasalahan yang menimbulkan penyakit masyarakat serta diharapkan agar Pemerintah lebih menyediakan lapangan pekerjaan agar tidak ada lagi penyakit masyarakat di Kabupaten Demak. Pemberian dana juga sangat dibutuhkan oleh aparat penegak hukum agar bisa berjalan dengan maksimal untuk memberantas penyakit masyarakat.

Aparat penegak hukum diharapkan juga agar lebih tegas berdasarkan Peraturan Daerah Nomor 2 tahun 2015 tentang Penanggulangan Penyakit Masyarakat di Kabupaten Demak, serta menambah personil dalam pelaksanaan penegakan hukum ini agar berjalan secara total untuk menanggulangi penyakit masyarakat ini. Aparat penegak hukum juga perlu melakukan penyuluhanpenyuluhan di berbagai sekolahsekolah dan wilayah- wilayah yang dianggap rawan terjadinya praktek prostitusi, kemudian memberikan sosialisasi mengenai bahayanya seks bebas dan penyakit yang dapat ditularkan.

\section{Daftar Pustaka}

\section{Literatur}

Anwar , Yasril dan Adang,2009, Sistem Peradilan Pidana. Bandung: Widya Padjadjaran. -2010. Kriminologi.

Bandung :Refleksi Aditama.

Arikunto,Suharsimi, 2006, Prosedur Penelitian Suatu Pendekatan

Praktik, Jakarta: Rineka Cipta.

Effend, M Erdianto,2011,Hukum Pidana Indonesia, Bandung: Refika Aditama

Farhan, 2010, Aspek Hukum Perdagangan Orang di Indonesia, Jakarta: Sinar Grafika

Hamzah, Andi. 2001. Hukum Acara Pidana Indonesia.Jakarta: Sinar Grafika.

Ibrahim, Johnny. 2006.Teori dan Metode Penelitian Hukum Normatif. Malang: Bayumedia Publishing.

Kartono, Kartini, 1981, Patologi Sosial Jilid I, Bandung: PT Raja Grafindo Persada.

Koentjoro,2004, Tutur dari Sarang Pelacur, Jogja: Qalam Yogyakarta

Muladi. 1995. Kapita Selekta Sistem PeradilanPidana. Universitas Diponegoro

Mulyadi, Lilik. 2007. Hukum Acara Pidana. Bandung: PT Alumni

Nardi. 2013. Prostitusi Sebagai Pionir Pengembangan Kota. Yogyakarta: Perpustakaan Gajah Mada.

Nawawi, Arif Barda. 2002. Bungan Rampai Kebijakan Hukum Pidana. Bandung:Citra Aditya. 
1982. Kebijakan

Penanggulangan Kejahatan

Dengan Hukum, Masalah-

Masalah Hukum. Fakultas

Hukum Universitas

Diponegoro.

Prasetyo, Teguh, 2010, Hukum

Pidana, Jakarta: Rajawali

Pers.

Prodjodikoro, Wirjono, 2003,Tindak-

Tindak Pidana Tertentu di

Indonesia,Bandung; $\quad$ PT

Refika Aditama.

Rahardjo, Satjipto. 1986. Masalah Penegakan Hukum. Bandung; Sinar Baru

Masyarakat,
Angkasa.

Sedyaningsih, Endang R, 2010, Perempuan - Perempuan Kramat Tunggak, Jakarta : Gramedia.

Sudarto, 1986, Hukum dan Hukum Pidana, Alumn, Bandung. --1990, Hukum Pidana I, yayasan Sudarto, Semarang.

Soekanto , Soerjono,2014, FaktorFaktor yang Mempengaruhi Penegakan Hukum, Jakarta: Rajawali Pers.

-2005, Sosiologis : Suatu Pengantar, Jakarta: Raja Grafindo Persada.

Soekanto, Soerjono\& Sri Mamudji, 2001, Penelitian Hukum Normatif (Suatu Tinjauan Singkta), Jakarta: Rajawali Pers.

Soemitro, Ronny Hanitijo,SH, 1998, Metodelogi Penelitian Hukum dan Jurimetri, Jakarta: Yudistir, Ghalia Indonesia.
Tjipto, Fandy, 2008, Strategi Pemasaran, Yogyakarta: Andi.

\section{Perundang- undangan}

Undang- Undang Dasar 1945 Pasal 7 ayat (2)

Peraturan Daerah Nomor 2 Tahun 2015 Tentang Penanggulangan Penyakit Masyarakat di Kabupaten Demak

Undang- Undang RI No. 2 Tahun 2002 Tentang UndangUndang Kepolisian.

Peraturan Pemerintah Republik Indonesia Nomor 6 Tahun 2010 Tentang Satuan Pamong Praja dan Kepolisian.

\section{Jurnal}

Admad Rosyadi. Jurnal. Kajian Yuridis Terhadap Prostitusi Online di Indonesia. Fakultas Syariah dan Hukum. Universitas Islam Negeri Syarif Hidayatullah Jakarta.2011

Bunga Desyana Pratami. Jurnal. Penegakan Hukum Atas Prostitusi di Beding Sari Desa Bendan Sari Kelurahan Kergon Jawa Tengah. Fakultas Hukum Universitas Islam Negeri Sunan Kalijaga Yogyakarta.2016

Suprojo. Jurnal. Penegakan Hukum Pidana Dalam Penanggulangan Pekerja Seks Komersial. Fakultas Hukum Universitas Negeri Semarang.2016

Syarifuddin. Prostitusi Sebagai Penyakit Sosial dan Problematika Penegakkan 
Hukum. Fakultas Hukum

Universitas Sumatera Utara

Tika Puspita Sari. Jurnal. Penegakan

Hukum Pidana Indonesia.

Fakultas Ilmu Tarbiyah dan

Keguruan IAIN Syekh

Nurjati Cirebon.2017 